\title{
Crystal pathologies in macromolecular crystallography
}

\begin{abstract}
$\mathbf{M}$

acromolecules, such as proteins or nucleic acids, form crystals with a large volume fraction of water, $\sim 50 \%$ on average. Apart from typical physical defects and rather trivial poor quality problems, macromolecular crystals, as essentially any crystals, can also suffer from several kinds of pathologies, in which everything seems to be perfect, except that from the structural point of view the interpretation may be very difficult, sometimes even impossible. A frequent nuisance is pseudosymmetry, or non-crystallographic symmetry (NCS), which is particularly nasty when it has translational character. Lattice-translocation defects, also called order-disorder twinning (OD-twinning), occur when molecules are packed regularly in layers but the layers are stacked (without rotation) in two (or more) discrete modes, with a unique translocation vector. Crystal twinning arises when twin domains have different orientations, incompatible with the symmetry of the crystal structure. There are also crystals in which the periodic (lattice) order is broken or absent altogether. When the strict short-range translational order from one unit cell to the next is lost but the long-range order is restored by a periodic modulation, we have a modulated crystal structure. In quasicrystals (not observed for macromolecules yet), the periodic order (in 3D space) is lost completely and the diffraction pattern (which is still discrete) cannot be even indexed using three $h k l$ indices. In addition, there are other physical defects and phenomena (such as high mosaicity, diffraction anisotropy, diffuse scattering, etc.) which make diffraction data processing and structure solution difficult or even impossible.
\end{abstract}

\section{INTRODUCTION}

To a casual observer, the crystallographic research process, which has amassed during less than 60 years over 100,000 astonishingly elegant and ground-breaking macromolecular structures, would appear to be a smooth and easy one. Such an impression could not be farther from the truth, as the work of a macromolecular crystallographer is in fact full of obstacles, struggles and traps. The difficulties connected with the crystals have been for a long time associated with the capricious process of macromolecular crystallization, while the crystals themselves could be either good or bad; the other hurdles were simply so tall that the unpromising crystal would be simply discarded and one would keep hopefully looking for a better one. The amount of experience that we have at hand today leads us to the conclusion that macromolecular crystals can suffer from about any pathology known to crystallography. We have however learned a lot and are able to attack problems that even not long ago would be dismissed as intractable. In this article, we wish to present in an accessible way an overview of the rich palette of diversified cases of crystal pathology that are known to macromolecular crystallographers. For want of a better word, we will be using the term "pathology" although it is quite misleading, as the situations we describe are often commonplace cases rather than rarities. Nevertheless, the term "pathologic" may still reflect our longing for the ideal crystal, which in the end may be the actual rarity.

Figure 1 presents in a simplified way an idealized crystal structure in direct space and the corresponding diffraction pattern in reciprocal space, to be compared with analogously illustrated manifestations of different pathologies presented in figures $2-5$.

\section{CRYSTALS OF THE MOLECULES OF LIFE}

Crystals formed by macromolecules, such as proteins or nucleic acids, are similar in many respects to crystals of ordinary organic molecules but there is a fundamental difference: the huge volume fraction of water, $~ 50 \%$ on average [1], but in practice anything between 20 and 90\%. Water envelopes the macromolecules in a pretty ordered hydration shell, to become totally disordered as bulk solvent farther away from the molecular surface. Because they are cloaked by water, the macromolecules in a crystal form only sporadic, weak direct con-

\section{Zbigniew Dauter ${ }^{1, \bowtie}$}

\section{Mariusz Jaskolski²}

${ }^{1}$ Macromolecular Crystallography Laboratory, National Cancer Institute, Argonne National Laboratory, Argonne, USA ${ }^{2}$ Department of Crystallography, Faculty of Chemistry, A. Mickiewicz University, Poznan, Poland, and Center for Biocrystallographic Research, Institute of Bioorganic Chemistry, Polish Academy of Sciences, Poznan, Poland

Macromolecular Crystallography Laboratory, National Cancer Institute, Argonne National Laboratory, Argonne, IL 60439, USA; e-mail: dauter@anl.gov

Received: February 13, 2016

Accepted: March 22, 2016

Key words: pseudosymmetry, non-crystallographic symmetry (NCS), translational NCS, crystal twinning, merohedry, lattice-translocation defects, order-disorder (OD), aperiodic crystals, superstructure, modulated structure, commensurate modulation, incommensurate modulation, quasicrystals, diffraction anisotropy, diffuse scattering, mosaicity

Dedication: We dedicate this work, with friendship, to Alex Wlodawer, who seems to attract (like us) - but also solve! - difficult crystallographic problems. 


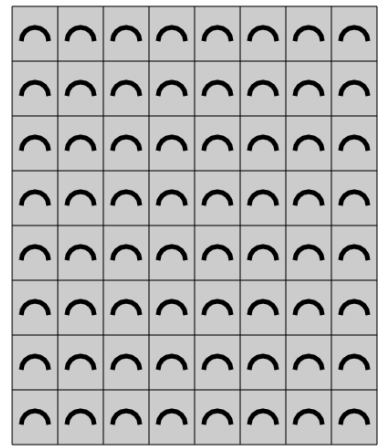

$\mathrm{b}$

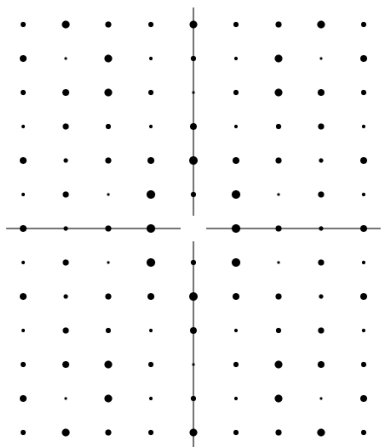

Figure 1. (a) Schematic representation of an idealized crystal in which the vertica axis is polar, i.e. the directions "up" and "down" are not equivalent. (b) In the hol layer of reciprocal space of a crystal with even-fold (vertical) axis, the reflections in the lower and upper parts are equally spaced, and have symmetrically equal intensities since the diffraction pattern is always centrosymmetric (according to Friedel's Law)

tacts and thus the degree of crystalline order is often less than perfect. Apart from typical physical lattice defects and rather trivial poor quality/habit/growth or mosaicity problems, macromolecular crystals, as essentially any crystals, can also suffer from several kinds of pathologies, in which everything seems to be perfect, except that from the structural point of view the interpretation may be very difficult, sometimes even impossible. For some time it was believed that certain types of pathologies are not found in the world of macromolecular crystals and, when encountered, such cases were swept under the carpet as rare curiosities. Today we have to admit that such pathologies are actually quite common.

Before characterizing in more detail selected cases (most common or most interesting, in our partial opinion) of crystal pathology one-by-one, it may be useful to give a nutshell outline of the methodology of protein crystallography. Interested readers may be directed to more comprehensive textbooks (e.g. [2]) or didactic reviews [3,4]. Briefly, a suitable single crystal (with a single periodic three-dimensional (3D) lattice, Fig. 1a) of the macromolecule of interest is exposed to a beam of (usually monochromatic, with a specific wavelength $\lambda$ ) X-rays to produce a diffraction pattern of scattered reflections (identified by integer $h k l$ indices in $3 \mathrm{D}$ ). The diffraction pattern (Fig. 1b) is recorded by an appropriate detector and stored in a computer as a set of reflection intensities $I(h k l)$ measured at the characteristic glancing angles $\theta(h k l)$, as dictated by the famous Bragg's Law, $\lambda=2 d(h k l) \sin \theta(h k l)$. The parameter $d$ measures distances in the crystal lattice, which is also referred to as real (or direct) lattice. This qualification is necessary because the diffraction pattern is in fact defined in a different space, called reciprocal space. This is so, because the diffraction pattern represents the Fourier transform of the real crystal structure, $F(h k l)=\int_{V} \rho[\cos 2 \pi(h x+k y+l z)+$ $i \sin 2 \pi(h x+k y+l z)] d V$ (with the integration over the unit cell ${ }^{1}$ volume $V$ ), where the structure factor $F(h k l)=|F(h k l)| e^{i \varphi(h k l)}$ is the wavevector of the corresponding reflection, $I(h k l)=$ $|F(h k l)|^{2}$. The power of the Fourier formula allows the crys-

${ }^{1}$ The unit cell is a minimal parallelepiped in a lattice, whose replication in three dimensions (3D) according to the three vectors $\mathbf{a}, \mathbf{b}, \mathbf{c}$ defining the axial system, recreates the periodic lattice. tallographer to calculate the distribution of electrons in the unit cell $\rho(x y z)$ (called the electron density) using inverse integration, or summation, as: $\rho(x y z)=V^{-1} \Sigma_{h k l} F(h k l)[\cos 2 \pi(h x-$ $+k y+l z)-i \sin 2 \pi(h x+k y+l z)]$. The problem (called the phase problem) with this simple solution is that the data reduction algorithm produces only the moduli $|F(h k l)|=\sqrt{ } I(h k l)$ of the structure factors, but not their phases $\varphi(h k l)$, which are indispensable for the calculation of $\rho(x y z)$ and have to be determined (solved) with reference to additional experiments, using crystals derivatized with special atoms (e.g. electron-rich markers of electron density), or to calculations. In the latter case, one may use a suitable model similar to the investigated macromolecule, hoping that molecular replacement algorithms will be able to figure out its orientation and location in the unit cell. In all cases, accurate information about the structure factor amplitudes $|F(h k l)|$ is essential, and this information is also required at the later stages of structure analysis, when a preliminary atomic model of the crystal structure is refined against the experimental data, with the aim of bringing the model-simulated (calculated) structure factors $\left(\left|F_{c}\right|\right)$ to close agreement with the observed ones $\left(\left|F_{0}\right|\right)$, as gauged, for example, by the crystallographic residual $R$-factor $\left(R=\Sigma|| F_{o}|-| F_{c}|| / \Sigma\left|F_{o}\right|\right)$.

\section{PSEUDOSYMMETRY}

The simplest, but also commonly encountered freak is pseudosymmetry, also called non-crystallographic symmetry (NCS), which could be an advantage, nuisance or real pathology [5]. With NCS, two or more molecules are related locally by some kind of symmetry transformation, which is not imposed by the symmetry of the crystal as a whole. For example, a circular pentameric oligomer may have exact five-fold symmetry, but such a rotation axis cannot be part of the set of crystallographic operations, called the space group. (To make things more confusing, parenthetically we note that five-fold symmetry is possible in non-periodic quasicrystals, vide infra.) In such a case the asymmetric unit (ASU) would contain five times more atoms than one unique molecule. Sometimes NCS may be beneficial, if the individual molecules can be assumed to be identical; this would reduce the number of parameters necessary to describe the structure. A very high level of NCS is helpful in solving the structures of icosahedral virus capsids, where sometimes the paucity of experimental data (measured re-

a

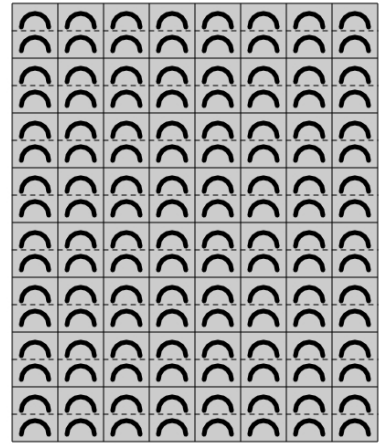

b

Figure 2. (a) A crystal characterized by tNCS, with two parallel molecules, shifted by a vector close to $1 / 2$ of the vertical lattice translation. (b) In the diffraction pattern of such a crystal the odd rows of reflections have much weaker intensities than the even rows. 
flection intensities) is compensated by many-fold repetition of an identical motif forming the capsid structure.

Translational NCS (tNCS) occurs when two or more molecules in the ASU are parallel and shifted by a vector that is a fraction of the crystal unit cell parameter, figure $2 a$. The consequences are then particularly nasty as this leads to strong bias in reflection intensity distribution, figure $2 b$. For example, if the NCS translation relating two molecules is $d x=0.48$ of the crystal a parameter, all reflections with the $h$-index odd $(h=2 n+1)$ will be much weaker than those with $h$ even $(h=2 n)$. This is easy to understand, as in the extreme situation with $d x=0.5$, the $h$ odd reflections disappear completely, and the unit cell becomes two times smaller. tNCS makes structure solution particularly difficult, and the standard procedures tend to push the whole structure to adopt the idealized smaller cell, since only very weak reflections contain the information about the small differences between the idealized positions and orientations of the molecules related by the tNCS. Methodologically, such an approach is rather dubious.

\section{CRYSTAL TWINNING}

Crystal twinning arises when separate twin domains within one specimen have different orientation dictated by a symmetry operation that is not part of the point group symmetry of the crystal structure. When the extra twin operation belongs to the same crystal system, the alignment of the twin domains, and of the overlapping reflections, is exact and this case is termed merohedral twinning (Fig. 3). Obviously, in macromolecular crystallography the twin operations may only be proper rotations. Merohedral twinning may, for example, occur for crystals of class 4 (space groups $\left.P 4, P 4_{1}, P 4_{2}, P 4_{3}, I 4, I 4_{1}\right)$ where the four-fold axis is polar, i.e. its two directions are nonequivalent. If in the separate do-
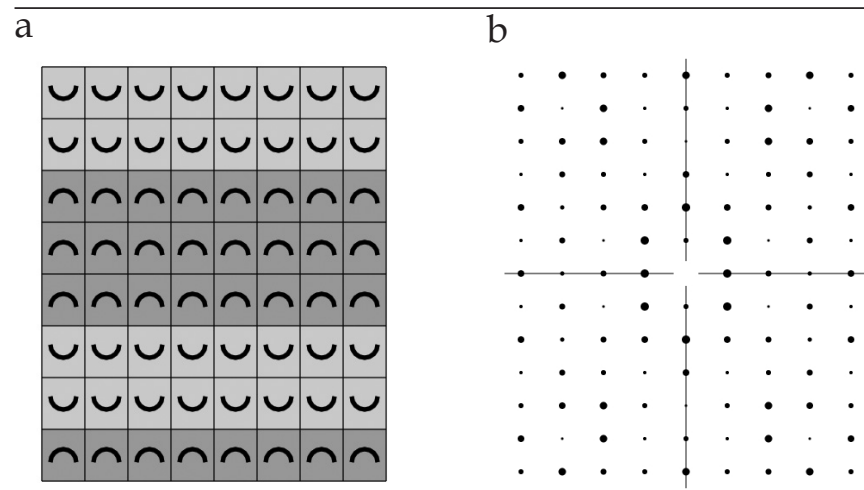

C

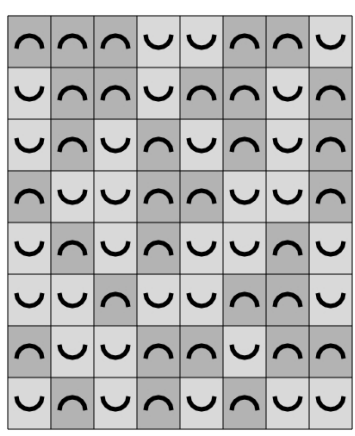

Figure 3. (a) A merohedrally twinned crystal in which separate domains (depicted in two shades of gray) are antiparallel to each other. (b) If the total volumes of the two domains are equal, the diffraction pattern acquires higher symmetry than the true symmetry of the crystal structure, resulting in the equivalence of the upper and lower parts. In variance with the domain structure of a twinned crystal (a), in a crystal with static disorder (c) individual unit cells assume different orientation randomly. mains of such a crystal the polarity of the four-fold axis is inverted, the specimen will mimic the higher symmetry class 422 of the tetragonal system. If the overall volumes of the two twin domains are equal, the recorded reflection intensities from such a perfect twin will conform exactly to the 422 class, which is higher than the real symmetry of the crystal structure. If the volumes of twin domains are not equal, the twinning is partial. Merohedral twinning may occur in protein crystallography in the following crystal classes with polar rotation axes: 4, 3, 32, 6, 23 .

Pseudomerohedral twinning arises when a low-symmetry unit cell has parameters with higher metric symmetry (e.g. the monoclinic angle $\beta=90^{\circ}$ ). When the twin domains adopt two orientations the twinning is hemihedral, when four - tetartohedral, eight - ogdohedral. Tetartohedral twinning may occur in crystal symmetry $P 3$, since the genuine three-fold axis may be accommodated (in different domains) in a hexagonal (at least 622) lattice in four orientations: (i) the original one, (ii) rotated $180^{\circ}$ around $\mathrm{c}$, (iii) rotated $180^{\circ}$ around a, and (iv) rotated $180^{\circ}$ around the $a, b$ diagonal. In this case, any of the three two-fold axes from the lattice symmetry (but not from the crystal class) may be selected as the twin operation.

The separate twin domains scatter X-rays independently (incoherently) and therefore the scattered intensity recorded for a twinned crystal correspond to the sum of reflection intensities originating from the individual domains. In contrast, in a "healthy" crystal all the unit cells scatter in phase, and the total effect corresponds to the sum of amplitudes. Thus, the intensity distribution corresponding to a twinned crystal deviates from the standard Wilson statistics [6,7]. Each individual single crystal produces X-ray diffraction data with a certain fraction of very weak and very strong reflections. In the case of twinning, there is a rather low probability that overlapping reflections from the twin domains will be both very weak or both very strong. The diffraction data of a twinned crystal have therefore a more uniform intensity distribution, with less very weak and very strong reflections than expected $[8,9]$.

Since diffraction patterns originating from all twin domains overlap perfectly, twin detection and assessment have to rely on intensity data statistics. They are based on the overall statistical characteristics of all data, such as the moments of intensities $\left\langle I^{2}\right\rangle /\langle I\rangle^{2}$ and the cumulative intensity distribution $N(z)$-test [10], or on comparison of reflection pairs related by the twinning operation, such as the $I_{1} /$ $I_{2}$ test [11], the negative intensity Britton-test $[12,13]$, or the $S(H)$-test $[14,15]$. The tests are complicated by the fact that some other pathologies (e.g. tNCS) have the opposite effect on intensity statistics, but the L-test [16] is especially robust in such cases.

If the twinning fraction is small, structure solution is usually not seriously hampered, but the situation gets worse with higher twinning fractions and is particularly difficult at $50 \%$ twinning. Once the structure is solved, all popular refinement programs are capable of refining the atomic models taking the twinning phenomenon properly into account. For example, the program REFMAC [17] is very clev- 


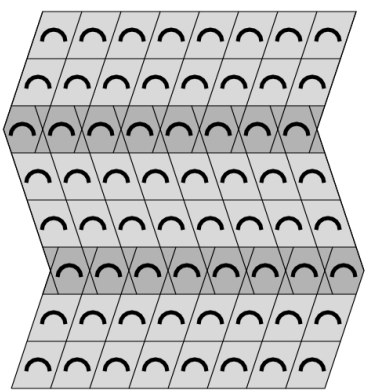

$\mathrm{b}$

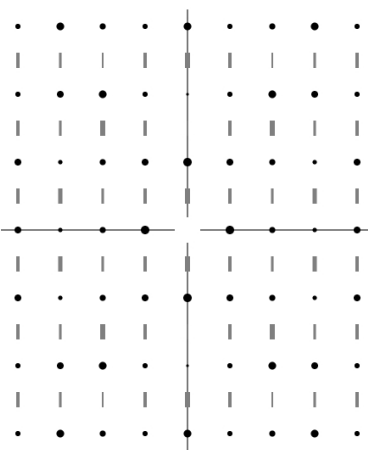

Figure 4. (a) A simplified representation of a crystal suffering from lattice translocation, where layers of unit cells are shifted in one or the other direction (horizontally), but the spatial relation between all consecutive pairs of layers (in the vertical direction) is identical. (b) In the diffraction pattern of such a crystal, reflections of one class are streaked or diffused and weak, whereas other reflections are not affected.

er in such situations because it can also automatically detect, establish and refine the twinning model.

Crystal twinning (illustrated in Fig. 3a) should not be confused with static disorder (Fig. 3c), where unit cells with molecules oriented in two (or more) ways are distributed randomly throughout the crystal.

\section{LATTICE-TRANSLOCATION DEFECTS}

Lattice-translocation defects, also known as order-disorder (OD) twinning, occur when molecules are packed regularly in layers but the layers are stacked (without rotation) in a pattern of two or more discrete modes, with a unique translocation vector, figure $4 \mathrm{a}$. Molecules in the incorrectly stacked layers scatter coherently, but with a characteristic phase shift. In the diffraction pattern, OD defects are manifested by the coexistence of two subsets of reflections: strong and sharp ones, and weak and streaky ones, figure $4 b[18,19]$. Another manifestation of lattice-translocation defects is a high non-origin Patterson peak resulting from the strong-weak modulation of reflection intensities. Non-origin Patterson peaks are also associated with other pathologies, such as tNCS pseudosymmetry, but the combination with a strong-weak/ sharp-smeared diffraction pattern is a telltale feature of lattice-translocation defects. An OD crystal structure may be refined as independent overlapping models or (as one model) with appropriate account of the translocation vector [20].

\section{MODULATED STRUCTURES}

There are also crystals in which the periodic (lattice) order is broken or absent altogether. When the strict short-range translational order from one unit cell to the next is lost but the long-range order is restored by a periodic Atomic Modulation Function (AMF) $\Psi$, we have a modulated crystal structure, figure $5 \mathrm{a}$. If the period of $\Psi$ runs over an integral number of unit cells, as in figure $5 b$, the modulation is commensurate and can be interpreted as a case of tNCS, with an enlarged unit cell (supercell).

a periodic

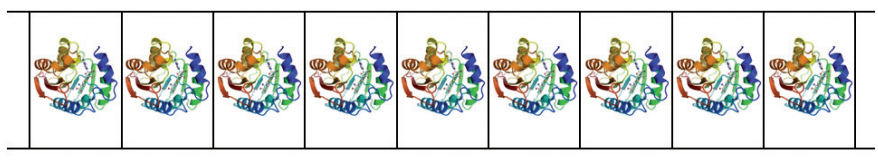

commensurate $\left(q=0.25 c^{*}\right)$

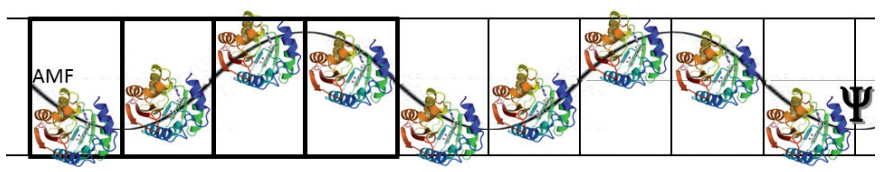

incommensurate $\left(q=0.2735 \ldots c^{*}\right)$

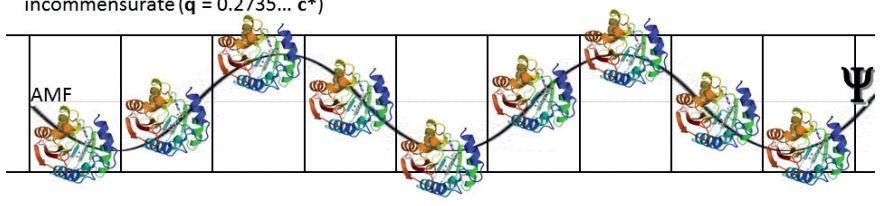

b

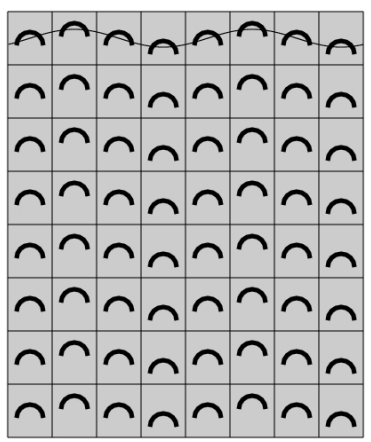

C

d

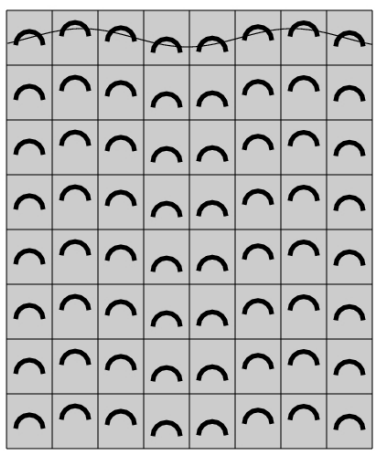

e

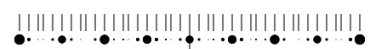

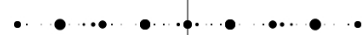

$\bullet . . . . . . \bullet . . . \bullet \bullet \ldots . .$.

๑...................

......................

$\bullet \ldots . . . \cdot \bullet \ldots \bullet \ldots . . . . \bullet \bullet \bullet . . . \bullet \bullet$

$\because \bullet \bullet \bullet \bullet-\bullet \bullet \bullet \cdots$

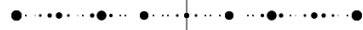

.......................

๑.....................

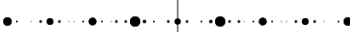

-...๑ ๑...........

$\bullet \cdot \bullet \bullet \bullet \cdots \bullet \bullet . . . \bullet \bullet \bullet \bullet \bullet \bullet$

Figure 5. (a) Schematic illustration of a perfectly periodic (top), commensurately modulated (middle) and incommensurately modulated (bottom) structures, with the corresponding Atomic Modulation Functions $\Psi$. "(b) In this example of commensurate modulation, the periodicity is restored after four unit cells, and in the diffraction pattern (c) the original spacing between the strong main reflections is divided by three additional, equally spaced, much weaker satellite reflections. (d) In the case of incommensurate modulation, the AMF periodicity is not congruent with the periodicity of the crystal lattice, and in the diffraction pattern (e) the satellite reflections are irregularly spaced around the main reflections.

Otherwise the modulation is incommensurate (Fig. $5 \mathrm{~d}$ ) and such a structure is very difficult to solve, refine and interpret. Its proper description is possible in a multidimensional (more than $3 \mathrm{D}$ ) superspace. A modulated crystal structure is referred to as superstructure. The diffraction pattern of a modulated crystal contains strong main reflections (corresponding to the underlying basic unit cell) and of much weaker (and closely spaced) satellite reflections corresponding to the periodic modulation wave 
$\Psi$. When the modulation is commensurate, the satellite reflections divide the spaces between the main reflections in an integral number of equal divisions (Fig. 5c) corresponding to the so-called modulation vector $\mathbf{q}^{*}$ having a rational definition in reciprocal lattice. With incommensurate modulation the $\mathbf{q}^{*}$ vector has at least one irrational component and the diffraction pattern cannot be indexed using three integer numbers $h k l$. Instead, additional (one or more) indices $m$ are needed, referring to the $\mathbf{q}^{*}$ vector(s), figure $5 \mathrm{e}$.

Modulated structures are relatively well known in small-molecule crystallography [21] but in protein crystallography are almost unheard of (probably because such cases, even if encountered, were discarded in the past as too difficult) although attempts have been made to investigate them methodically [22,23]. In cases of incommensurate modulation even the data processing [24] might be an insurmountable problem. One of the few successfully tackled modulated protein crystal structures is that of the plant protein Hyp-1 in complex with the fluorescent dye ANS, which was successfully solved by molecular replacement with tNCS-adjusted maximum-likelihood targets [25] and described as a tetartohedrally twinned commensurate phase with seven-fold expanded unit cell containing 28 independent protein molecules [26]. Further analysis suggests, however, that the commensurate model may be only an approximate one and the structure may be in fact incommensurately modulated (Sliwiak, unpublished results).

\section{QUASICRYSTALS}

In quasicrystals, the translational periodic order (in 3D space) is absent altogether and the diffraction pattern, which is still discrete, as first demonstrated by Mackay [27], cannot be indexed using three $h \mathrm{kl}$ indices. The structures do have, however, non-repetitive long-range orientational order, similar to the famous Penrose patterns (tilings) in two dimensions. A complicated mathematical theory developed by Janner and Janssen $[28,29]$ explains quasicrystals by evoking a periodic structure in a multidimensional (e.g. 6D) superspace, whose intersection by a 3D hyperplane (corresponding to our familiar 3D space) gives rise to a non-periodic construction. In addition to the lack of periodicity, quasicrystals are also often characterized by the presence of rotational symmetry, such as five-, ten- or twelve-fold, that is forbidden in classic periodic crystals. Observation of such forbidden symmetry in the diffraction patterns of his crystals, led Dan Shechtman [30] to the discovery of quasicrystals. This discovery, contested for a long time by such champions as Linus Pauling, was finally fully recognized and awarded with a Nobel Prize.

Among the pathologies presented in this review, only the fully aperiodic quasicrystals have not been reported so far for macromolecular crystals. But this may only be a matter of time.

\section{DIFFUSE SCATTERING}

Diffuse scattering, which arises as a result of departure from perfect crystalline order, has the appearance of streaks or smeared (or nebulous) scattering and is usually observed outside of Bragg peaks. The underlying cause may be lattice defects, static disorder of the molecules (displacements from average positions), or concerted motion of molecules in the crystal lattice. In the latter case, there may be waves of displacement traveling through the crystal, which are termed phonons and which give rise to so-called thermal diffuse scattering (TDS).

\section{OTHER CASES}

The pathologies of the physical crystal and/or its structure are usually manifested in the diffraction pattern, which can be anisotropic, contain diffuse scattering and/or split, overlapping or smeared reflections, as well as extra reflections or diffraction rings ("powder diagram") arising from solid ice and buffer components recrystallized during suboptimal refrigeration ("freezing") of the protein crystal. These "special effects" not only complicate the ultimate structure analysis but often make even the initial data processing problematic or impossible.

\section{REFEREN ES}

1. Matthews BW (1968) Solvent content of protein crystals. J Mol Biol 33: 491-497

2. Rupp B (2009) Biomolecular Crystallography: Principles, Practice, and Application to Structural Biology. New York: Garland Science

3. Wlodawer A, Minor W, Dauter Z, Jaskolski M (2008) Protein crystallography for non-crystallographers, or how to get the best (but not more) from published macromolecular structures. FEBS J 275: 1-21

4. Wlodawer A, Minor W, Dauter Z, Jaskolski M (2013) Protein crystallography for aspiring crystallographers, or how to avoid pitfalls and traps in macromolecular structure determination. FEBS J 280: 5705-5736

5. Zwart PH, Grosse-Kunstleve RW, Lebedev AA, Murshudov GN, Adams PD (2008) Surprises and pitfalls arising from (pseudo)symmetry. Acta Cryst D64: 99-107

6. Wilson AJC (1942) Determination of absolute from relative X-ray intensity data. Nature 150: 152

7. Wilson AJC (1949) The probability distribution of X-ray intensities. Acta Cryst 2: 318-321

8. Stanley E (1955) The distribution of the mean intensity of a finite group of reflections. Acta Cryst 8: 351-352

9. Stanley E (1972) The identification of twins form intensity statistics. J Appl Cryst 5: 191-194

10. Rees DC (1980) The influence of twinning by merohedry on intensity statistics. Acta Cryst A36: 578-581

11. Murray-Rust P (1973) The crystal structure of $\left.\left.\mathrm{Co}\left(\mathrm{NH}_{3}\right)_{6}\right)\right]_{4} \mathrm{Cu}_{5} \mathrm{Cl}_{17}$ : a twinned cubic crystal. Acta Cryst B29: 2559-2566

12. Britton D (1972) Estimation of twinning parameter for twins with exactly superimposed reciprocal lattices. Acta Cryst A28: 296-297

13. Fisher RG, Sweet RM (1980) Treatment of diffraction data from protein crystals twinned by merohedry. Acta Cryst A36: 755-760

14. Yeates TO (1988) Simple statistics for intensity data from twinned crystals. Acta Cryst A44: 142-144

15. Yeates TO (1997) Detecting and overcoming crystal twinning. Methods Enzymol 276: 344-358

16. Padilla JE, Yeates TO (2003) A statistic for local intensity differences: robustness to anisotropy and pseudo-centering and utility for detection of twinning. Acta Cryst D59: 1124-1130 
17. Murshudov GN, Skubak P, Lebedev AA, Pannu NS, Steiner RA, Nicholls RA, Winn MD, Long F, Vagin AA (2011) REFMAC5 for the refinement of macromolecular crystal structures. Acta Cryst D67: 355-367

18. Bragg WL, Howells ER (1954) X-ray diffraction by imidazole methaemoglobin. Acta Cryst 7: 409-411

19. Dornberger-Schiff K (1956) On order-disorder structures (OD-structures). Acta Cryst 9: 593-601

20. Zhu X, Xu X, Wilson IA (2008) Structure determination of the 1918 H1N1 neuraminidase from a crystal with lattice-translocation defects. Acta Cryst D64: 843-850

21. Wagner T, Schönleber A (2009) A non-mathematical introduction to the superspace description of modulated structures. Acta Cryst B65: 249-268

22. Lovelace JJ, Murphy CR, Daniels L, Narayan K, Schutt CE, Lindberg U, Svensson C, Borgstahl GEO (2008) Protein crystals can be incommensurately modulated. J Appl Cryst 41: 600-605

23. Lovelace JJ, Simone PD, Petricek V, Borgstahl GEO (2013) Simulation of modulated protein crystal structure and diffraction data in a supercell and in superspace. Acta Cryst D69: 1062-1072

24. Porta J, Lovelace JJ, Schreurs AMM, Kroon-Batenburg LMJ, Borgstahl GEO (2011) Processing incommensurately modulated protein diffraction data with Eval15. Acta Cryst D67: 628-638
25. Sliwiak J, Jaskolski M, Dauter Z, McCoy AJ, Read RJ (2014) Likelihood-based molecular-replacement solution of a highly pathological crystal with tetartohedral twinning and sevenfold translational non-crystallographic symmetry. Acta Cryst D70: 471-480

26. Sliwiak J, Dauter Z, Kowiel M, McCoy AJ, Read RJ, Jaskolski M (2015) ANS complex of St John's wort PR-10 protein with 28 copies in the asymmetric unit: a fiendish combination of pseudosymmetry and tetartohedral twinning. Acta Cryst D71: 829-843

27. Mackay AL (1986) Pauling's model not universally accepted. Nature 319: 103-104

28. Janssen T (1986) Crystallography of quasi-crystals. Acta Cryst A42: 261-271

29. Janssen T, Janner A, Looijenga-Vos A, De Wolff PM (1992) Incommensurate and commensurate modulated structures. International Tables for Crystallography, vol. C, pp. 899-947

30. Shechtman D, Blech I, Gratias D, Cahn JW (1984) Metallic phase with long-range orientational order and no translational symmetry. Phys Rev Lett 53: 1951-1953

\section{Patologie kryształów makromolekularnych}

\section{Zbigniew Dauter $^{1, \bowtie}$, Mariusz Jaskólski ${ }^{2}$}

${ }^{1}$ Macromolecular Crystallography Laboratory, National Cancer Institute, Argonne National Laboratory, Argonne, IL 60439, USA ${ }^{2}$ Zakład Krystalografii, Wydział Chemii, Uniwersytet im. A. Mickiewicza w Poznaniu, ul. Grunwaldzka 6, 60-780 Poznań i Centrum Badań Biokrystalograficznych, Instytut Chemii Bioorganicznej PAN, ul. Z. Noskowskiego 12/14, 61-704 Poznań, Polska

e-mail: dauter@anl.gov

Słowa kluczowe: pseudosymetria, symetria niekrystalograficzna (NCS), pseudosymetria translacyjna (tNCS), zbliźniaczenie kryształów, meroedria, translokacyjne defekty sieciowe, porządek-nieporządek (OD), kryształy aperiodyczne, nadstruktura, struktury modulowane, modulacja współmierna, modulacja niewspółmierna, kwazikryształy, dyfrakcja anizotropowa, rozpraszanie dyfuzyjne, mozaikowość

Dedykacja: Pracę tę dedykujemy w dowód przyjaźni dr Alexandrowi Wlodawerowi, który przyciąga (podobnie jak my) wszelakie problemy krystalograficzne, ale je również skutecznie rozwiązuje.

\section{STRESZCZENIE}

Makromolekuły życia, białka i kwasy nukleinowe, tworzą kryształy o ogromnej zawartości wody, średnio $50 \%$ objętości. Niezależnie od defektów fizycznych i trywialnego zagadnienia jakości, kryształy makromolekul, podobnie jak wszelkie inne kryształy, wykazują różnorodne patologie, gdy wszystko wygląda na pozór normalnie, z wyjątkiem tego, że interpretacja struktury jest nadzwyczaj skomplikowana lub wręcz niemożliwa. Zaskakująco często występuje pseudosymetria (nazywana również symetrią niekrystalograficzną NCS), która jest szczególnie kłopotliwa, gdy ma charakter translacyjny. Translokacyjne defekty sieciowe, zwane również zbliźniaczeniem typu porządek-nieporządek (OD), mają miejsce, gdy prawidłowo uformowane warstwy molekularne układają się z charakterystycznym błędem translacyjnym w płaszczyźnie warstwy. Zbliźniaczenie kryształu występuje, gdy domeny tworzące kryształ mają różną orientację, niezwiązaną z symetrią struktury kryształu. Znane są również kryształy, których okresowość, czyli charakter sieciowy, jest zaburzona cześciowo lub całkowicie. Gdy ścisły porządek translacyjny bliskiego zasiegu, od komórki do komórki, jest zaburzony, lecz periodyczność jest odzyskana dzięki okresowej modulacji tego zaburzenia, mamy do czynienia ze strukturą modulowaną. W kwazikryształach natomiast (jak dotąd nie napotkanych jeszcze w świecie makromolekuł biologicznych) okresowość w przestrzeni trójwymiarowej (3D) nie występuje w ogóle, a obrazu dyfrakcyjnego - który o dziwo jest dyskretny! - nie można wywskaźnikować przy użyciu trzech liczb całkowitych $\mathrm{hkl}$. Znane są także inne zjawiska o charakterze patologii, takie jak wysoka mozaikowość, anizotropowa dyfrakcja, czy rozpraszanie dyfuzyjne, które bardzo utrudniają, a niekiedy uniemożliwiają poprawną interpretację obrazów dyfrakcyjnych. 


\section{VOCABULARY AND GLOSSARY OF TERMS/ OBJAŚNIENIE TRUDNIEJSZYCH POJĘĆ}

Anisotropy - anizotropia to zależność wielkości fizycznej lub cechy od kierunku; brak takiej zależności oznacza izotropię. Kryształy makromolekuł moga wykazywać anizotropię dyfrakcji, kiedy refleksy mają mierzalne intensywności przy wyższej rozdzielczości $\mathrm{w}$ jednym kierunku, a nie $\mathrm{w}$ innym.

Aperiodic crystals - kryształy aperiodyczne mają budowę naruszającą zasadę ścisłej powtarzalności (okresowości) w trzech wymiarach.

Crystal twinning - zbliźniaczenie kryształu ma miejsce, gdy kryształ tworzą domeny o różnej orientacji, które związane są symetrią nie będącą elementem symetrii struktury tego kryształu.

Diffuse scattering - rozpraszanie dyfuzyjne pochodzi od skorelowanych drgań lub innych zjawisk typu "nieporządek” w sieci kryształu. Jeśli np. przez kryształ przechodzą fale oscylacji atomowych, one również mogą stać się „ośrodkiem” rozpraszania promieni $X$.

Lattice-translocation defects (OD-twinning) - translokacyjne defekty sieciowe powstają, gdy kryształ zbudowany jest $\mathrm{z}$ warstw, które przesunięte są względem siebie o wektor inny niż wektor translacji sieciowej. Ten efekt jest również określany jako zbliźniaczenie przez „porządek-nieporządek".

Merohedry - meroedria to symetria niższa niż najwyższa symetria (holoedria) danego układu krystalograficznego. Hemiedria zawiera połowę operacji symetrii holoedrii, tetartoedria jedną czwartą, a ogdoedria jedną ósmą. Bliźniak meroedryczny wykorzystuje wyższą symetrię tego samego układu krystalograficznego. Bliźniak pseudomeroedryczny "udaje” symetrię wyższego układu krystalograficznego dzięki nietypowym parametrom komórki elementarnej (np. kąt $\beta=90^{\circ} \mathrm{w}$ układzie jednoskośnym, lub $a=b \mathrm{w}$ układzie niskosymetrycznym).

Modulated structure - w strukturze modulowanej ścisła okresowość bliskiego zasięgu (od komórki do komórki) w jednym lub kilku kierunkach jest złamana, lecz okresowość dalekozasięgowa jest odzyskana dzięki periodycznej funkcji modulacji, która określa przebieg zmian od komórki do komórki. Jeśli okres funkcji modulacji jest całkowitą (n) wielokrotnością podstawowej komórki elementarnej, modulacja jest współmierna (commensurate) i można ją opisać w sposób klasyczny posługując się powiększoną (n razy) superkomórką elementarną. $\mathrm{W}$ przeciwnym razie modulacja jest niewspółmierna (incommensurate) i nie można jej opisać w sposób klasyczny, lecz trzeba się odwołać do opisu w (wielowymiarowej) superprzestrzeni.

Mosaicity - mozaikowość oznacza, że fizyczny kryształ złożony jest $\mathrm{z}$ odrębnych niewielkich bloków (mozaikowych), z których każdy ma odrębną sieć. Mozaikowość charakteryzują rozkład wielkości oraz orientacji bloków mozaikowych. W uproszczeniu mozaikowością nazywa się niekiedy drugi z tych parametrów.

Non-crystallographic symmetry (NCS) - symetria niekrystalograficzna (pseudosymetria), polegająca na współistnieniu w części asymetrycznej komórki elementarnej kilku kopii tej samej molekuły, które powiązane są przybliżoną symetrią nie należącą do symetrii grupy przestrzennej kryształu i działającą tylko lokalnie. Jeśli pseudosymetria ma charakter translacji (nie należącej do translacji sieciowych kryształu), oznacza się ją jako tNCS.

Order-disorder - porządek-nieporządek, inne określenie defektów translokacyjnych.

Quasicrystals - kwazikryształy nie mają żadnej periodyczności w trzech wymiarach (3D), a ich budowy nie można opisać posługując się siecią trójwymiarową. Nie mają więc one także komórki elementarnej znanej z kryształów klasycznych. Ich budowa dopuszcza symetrię (np. oś pięciokrotną) zabronioną dla kryształów o budowie sieciowej. Kwazikryształy można jednak opisać siecią periodyczną $\mathrm{w}$ superprzestrzeni wielowymiarowej (np. 6D). Obraz w 3D odpowiada przecięciu przestrzeni 6D przez ", hiperpłaszczyznę" niżejwymiarową.

Superstructure - nadstrukturą określa się strukturę kryształu z modulacją. 